\title{
Developing Library Facilities for Business Research
}

Miss Vormelker is head of the Business Information Bureau of the Cleveland Public Library.

$\mathrm{I}^{\mathrm{N}}$ NDUSTRIAL RESEARCH, usually identified with chemistry, physics, and engineering, has long been recognized as one of our outstanding and significant national resources. It has been represented in public and university library collections by a vast literature and specialization in the organization of science, engineering, and technology departments. Industrial research workers know how indispensable is a "literature search" on their problem before it becomes grist for the laboratory mill.

Business research, however, is a more recent development. It is known by many other phrases, some of which are economic research, statistical research, commercial research, financial research, social science research, management research, and market research. Frequently, too, the word "analysis" is used in place of "research." It is not easily defined because many of its facets have intangible characteristics. In an effort to define the field as a working basis for the study of business research as conducted in this country, recently directed by Dr. John H. Cover, ${ }^{1}$ the following criteria were adopted: ( $\mathrm{I}$ ) analysis of factors leading toward general 1 Report of an Advisory Committee of the Social
Science Research Council to the National Resources Planning Board. 1941. principles and interrelationships; (2) relating the derived conclusions or discovered factors to economic (or other) principles.

Business research concerns itself with what has been referred to as the "five m's," management, men, materials, markets, and money, and involves study in the fields of economics, statistics, finance, industrial and labor relations, psychology, geography, factory production, transportation, government regulations and legislation, business administration, the business functions of purchasing and distribution, education, and other fields, all of which are represented by a voluminous and rapidly growing literature. Business researchers are not as aware of the literature of their field as are industrial researchers. They are not always products of collegiate business schools where its development might have been introduced to them. But perhaps of more significance from the standpoint of public libraries, they have inherited opinions characteristic of many businessmen of the past, that no book could have any pertinent value for their work and, as libraries are institutions of books, it naturally follows in their thinking that there is little in public libraries in the field of business research which is of use to them.

Business branches such as those established in the business centers of Boston, Indianapolis, Newark, Pittsburgh, and 
San Francisco have helped to focus attention on this type of literature, and so gradually they help dispel that error of thought. While all of these branches emphasize quick reference and circulation service rather than maintaining extensive files of data for extended research, they still are potential centers for such research.

Libraries whose main building is in a business center have a distinct advantage in having vast resources for research at hand, but it is still necessary to focus attention on these facilities in some special way. In the Cleveland Public Library it was done by establishing a Business Information Bureau within the main building, transferring to it some of the materials of business research from other divisions in order that they might be as readily available as though segregated in a business branch and, at the same time, remain part of a huge original collection constituting research data. In a library organized into divisions on the basis of a modified Dewey Decimal Classification this was no easy task, for practically every division contained some materials needed for business research. It required keen vision, infinite patience, and a growing realization that, by setting up a focal unit for calling attention of this specialized clientele to the library, the significance of all library units has been enhanced.

\section{The Collection}

The limitations of architecture and marble have not yet been overcome, and an instantaneous observation of even a casual visitor is that the space allotted to the bureau, which is on the second floor of the main library building flanked on either side by the sociology division and the technology division, is most inadequate. Though this is all too true, it still is sig- nificant to note that with these limitations there have been assembled to date approximately sixty thousand books; one thousand American trade directories; fifty trade directories of foreign countries, largely for Latin America; ten thousand trade catalogs; fifteen hundred trade, management, and labor periodicals, including five hundred house organs; financial reports from approximately seven thousand corporations; and several hundred thousand pamphlets, typewritten or mimeographed special reports, and clippings. Of the trade periodicals received, about half are bound for permanent files while the rest are kept for varying periods or clipped after the current year. One group of resources usually identified with business library service-namely, the city and telephone directories-is in the general reference division, which houses also an extensive map collection. Both groups are available to the bureau as needed, as are also over two hundred newspapers on file in the newspaper room. Many other extensive sets in other divisions which would classify as business research material under a more adequate classification system have not been duplicated for, nor transferred to, the bureau but are made available as needed. These are dull and cold statistics but they serve to indicate, quantitatively, the extent to which facilities for business research, as well as for quick reference, have been segregated and correlated with the work of other divisions in Cleveland's main library.

But discovery and organization of materials in this field, as in others, is but the beginning of the library's opportunity. For reasons mentioned above, there is a greater need of lively dissemination of the information so assembled than is generally realized. The business research librarians 
must become identified with the professional associations in this field; e.g., the American Statistical Association, the American Economic Association, the Special Libraries Association, and the American Marketing Association. This thought has been frequently expressed in professional library literature, but an examination of the membership lists of these associations still reveals comparatively few librarians. Librarians would find that new point of view needed if they would heed the unexpressed call, "Come over into Macedonia and help us"-unexpressed, for they have so little conception of the extent of data available or of the ability of librarians to find them.

Lists and bulletins help, of course, but are most effective when arranged to appear at the psychological moment when need for the information contained therein is expressed. In the postwar plans the need for this type of research can scarcely be overestimated. Whether in the postwar world there be more government regulation and less free enterprise or more free enterprise and less government regulation, the fact remains that many men and women will be seeking jobs, which in turn will be greatly affected by economic forces which lend themselves to study.

\section{Securing Ephemera}

Often the librarian must search for the possible existence of materials needed by consulting private and government organizations rather than depend wholly upon published trade list sources, indispensable as they are. For instance, many organizations compile employee manuals which include discussion of incentive plans and suggestion systems. Very few of these ever reach the columns of library indexes or publishers' trade lists, yet it would be difficult to find more authoritative or practically presented information on the subject. One might go on indefinitely along this line and mention such timely subjects as correspondence manuals and bulletins, budget procedure manuals for government agencies, pension plans, wage and salary surveys.

For guidance and direction to this elusive ephemera, it is necessary to "listen in" on numerous conferences and to scan trade, commercial, professional, technical, and general magazines, newspapers, and services for announcements of research in progress or of reports, copies of which might be made available. Among the more important publications for this purpose are:

\section{Advanced Management}

Advertising Age

American Economic Review

Babson's Reports

Banking (American Bankers Association)

Barron's

Business Week

Chester Wright's Labor Letter

Domestic Commerce

Dun's Review

Economic Notes (Labor Research Association)

Harvard Business Review

Journal of Accountancy

Journal of American Statistical Association

Journal of Commerce

Kiplinger $W$ ashington Letter

Management Record

Management Review

Mechanical Engineering

Monthly Labor Review

National Association of Cost Accountants Bulletin

Nation's Business

New York Herald Tribune

New York Times

Newsweek

$P M$

Personnel Journal 
Planning for Post War (Griswold Newsletter)

Printers' Ink

Research Reports (American Institute for Economic Research)

Sales Management

Standard E Poor's Guide to Current Business Literature

Time

Traffic World

Wall Street Journal

Whaley Eaton Letters

and others. Information afforded through government agencies is often first noted in mimeographed press releases. Therefore, it is necessary that these, too, be carefully scanned to learn of similar data available from this source.

\section{Several Classifications}

To say that any piece of print or near print may logically classify in more than one place in any classification is falling into the obvious. Yet the significance of this has great meaning for the field of library service under discussion. Recently a letter was received in this bureau which said in part:

In a recent discussion, a question arose which was not satisfactorily answered and on which we feel you may have some ideas.

Is the history of an industrial or commercial organization, prepared from the viewpoint of its economic contributions, of interest and value to the library or libraries located in the community or communities served by such organizations?

We have never seen such works in public libraries and have often wondered if libraries were not interested.

Here is a specific case which illustrates the need for making business research materials available by form as well as by subject matter. There is no doubt that many libraries have found this kind of material very useful, but the experience of the inquirer shows how difficult it would be to locate when considered from the form standpoint.

\section{Consider Related Subjects}

In developing service according to group needs, such as the one under discussion, it is necessary to consider related subjects which will be constantly changing. Indeed, there probably is no field to which one might apply more appropriately the word "change," in describing its most constant characteristic, than the field of business research. Time was when psychology and geography were primarily classroom subjects. Now they are a vital part of any collection dealing with personnel training or market studies. What changes the present World War will develop for our future economic life are only being guessed and range from fears of widespread unemployment and dislocation of workers to miracles of development in industrial progress for both producer and consumer goods, assuring more of the good things of life for more people. That these changes may be brought about sanely and with least distress will require profound judgment, which depends upon information, much of which falls within the scope of business research. Information will be needed as never before on training and retraining of workers, potential markets, trading areas, transportation facilities, sources of raw materials, warehousing, distribution, financial operations, cost studies, time studies, economic conditions, cost of living, industrial and public relations, and many other subjects related to these fields.

The library has an unprecedented opportunity on its doorstep. May it keep the faith! 